\title{
Efektifitas Aktivitas Peer Group terhadap Penurunan Berat Badan dan Persen Lemak Tubuh pada Remaja Overweight
}

\author{
Effectiveness of Peer Group Activity on Reducing Body Weight and Body Fat Percentage in \\ Overweight Teenagers
}

\author{
Mohammad Jaelani, Meirina Dwi L, Ana Yuliah R, Ria Ambarwati \\ Jurusan Gizi Politeknik Kesehatan Kementerian Kesehatan Semarang
}

\begin{abstract}
ABSTRAK
Diet rendah energi dan peningkatan aktivitas secara individual belum efektif dalam penurunan berat badan. Oleh karena itu, perlu dicari metode lain atau memodifikasi metode dengan membentuk kelompok peer group aktivitas. Tujuan penelitian ini menganalisis efektifitas aktivitas peer group terhadap kepatuhan aktivitas fisik, kepatuhan diet, penurunan berat badan dan persen lemak tubuh pada remaja overweight. Desain penelitian menggunakan Randomized Controlled Trial dengan rancangan eksperimental ulang pre-posttest control group design. Subjek penelitian adalah remaja putri overweight sebanyak 13 orang kelompok kontrol dan 13 orang kelompok perlakuan. Subjek dilakukan intervensi berupa jogging minimal 30 menit dan naik turun tangga sebanyak 10 kali per hari selama empat minggu. Ukuran kepatuhan diet diambil setiap minggu berdasarkan hasil recall 2x24 jam selama 4 minggu. Perbedaan kepatuhan aktivitas fisik dan kepatuhan diet diuji menggunakan Chi Square Test sedangkan perubahan berat badan dan persen lemak tubuh menggunakan ANOVA Repeated Measure Test. Ada perbedaan yang signifikan antara kepatuhan aktivitas fisik $(p=0,000)$ dan penurunan berat badan $(p=0,004)$ antara kelompok perlakuan dan kontrol namun tidak ada perbedaan yang signifikan antara kepatuhan diet $(p>0,05)$ dan penurunan persen lemak tubuh $(p=0,382)$ antara kelompok perlakuan dan kontrol. Peer group efektif dalam meningkatkan aktivitas fisik dan menurunkan berat badan pada remaja overweight.
\end{abstract}

Kata Kunci: Aktivitas, penurunan berat badan, lemak tubuh, peergroup

\begin{abstract}
Individually, low-energy diet and increased activity have not been effective in weight loss. Therefore, it is necessary to find other methods or modify the method by forming groups of peer group activities. The purpose of this study was to analyze the effectiveness of peer group activities on adherence to physical activity, dietary compliance, and weight and body fat percentage loss in overweight adolescents. The study design used was Randomized Controlled Trial with re-experimental designed pre-posttest control group design. Subjects were overweight female teenagers as many as 13 people in the control group and 13 in the treatment group. Subjects were intervened in the form of jogging for at least 30 minutes and going up and down stairs 10 times per day for four weeks. A measure of dietary compliance was taken every week based on $2 \times 24$ hours recall results for 4 weeks. Differences in compliance with physical activity and dietary compliance were tested using Chi Square Test, while changes in body weight and body fat percentage were using ANOVA Repeated Measure Test. There is a significant difference between physical activity adherence $(p=0.000)$ and weight loss $(p=0.004)$ between the treatment and control groups, but there is no significant difference between dietary compliance $(p>0.05)$ and a decrease in body fat percentage $(p=0.382)$ between treatment and control groups. Peer groups are effective in increasing physical activity and losing weight in overweight teenagers.
\end{abstract}

Keywords: Activity, body fat, peer group, weight loss

Korespondensi: Mohammad Jaelani. Jurusan Gizi Politeknik Kesehatan Kementerian Kesehatan Semarang, Jl. Wolter Monginsidi 115 Pedurungan Semarang Tel. (024) 6710378 Email: 10jaelani.gizi@gmail.com

DOI: http://dx.doi.org/10.21776/ub.jkb.2018.030.02.9 


\section{PENDAHULUAN}

Prevalensi obesitas secara nasional tahun 2013 pada perempuan lebih tinggi dibandingkan laki-laki yaitu masing-masing 32,9\% dan 19,7\%. Prevalensi obesitas pada perempuan dengan umur $>18$ tahun terus meningkat dari tahun 2007 sampai 2013 yaitu semula $13,9 \%$ menjadi $32,9 \%$. (1). Berat badan dan bentuk tubuh menjadi hal yang biasanya diperhatikan oleh remaja dan dihubungkan dengan perilaku kontrol berat badan yang tidak sehat (2).

Remaja putri cenderung memiliki masalah terhadap strategi kontrol berat badan dan pengaturan makan (3). Biasanya remaja telah dapat menentukan makanan yang diinginkannya dan seringkali menjalani pola makan yang salah seperti tidak sarapan pagi, lebih memilih mengkonsumsi makanan cepat saji tinggi energi rendah zat gizi mikro dan rendahnya konsumsi serat (4) serta sering mengkonsumsi makanan di luar rumah. Kebiasaan ini menyebabkan remaja mengkonsumsi makanan yang padat energi yang diperberat dengan rendahnya aktivitas fisik sehingga berpotensi mengalami overweight $(5,6)$ dan berisiko menderita overweight saat dewasa. Hal ini juga dihubungkan dengan komplikasi kesehatan seperti hipertensi, diabetes melitus, dislipidemia, dan penyakit kardiovaskuler (7).

Metode yang lazim di gunakan untuk menurunkan berat badan adalah dengan diet rendah energi dan peningkatan aktivitas secara individual, namun cara tersebut belum konsisten dan efektif untuk menurunkan berat badan. Oleh karena itu perlu dicari metode lain atau memodifikasi metode yang sudah ada, diantaranya dengan membentuk kelompok atau peer group activity. Peer group sebagai kelompok perasaan senasib dalam memenuhi kebutuhan dan tujuan bersama. Peer group berkaitan dengan dukungan sosial terhadap perubahan perilaku kesehatan (8). Peer group dapat pula mempengaruhi peningkatan aktivitas fisik dan berkaitan dengan pengaturan berat badan remaja $(8,9)$. Peer group pun menentukan faktor gaya hidup remaja terkait kesehatan (10) yang berdampak pada pencegahan dan penanganan obesitas remaja (11).

Pengaruh peer group penting dalam pengembangan citra tubuh dan terkait dengan kepuasan tubuh di kalangan remaja dan telah terbukti meningkatkan aktivitas fisik dan memotivasi untuk berolahraga (7). Hal ini sesuai pendapat Woolford et al., yang menyatakan bahwa pengaturan berat badan remaja dipengaruhi oleh paparan informasi, aktivitas fisik dan dukungan dari peer group (12). Metode penurunan berat badan yang efektif belum jelas. Upaya penurunan berat badan seperti pengaturan makan disertai peningkatan aktivitas fisik secara individual belum dapat memberikan hasil yang maksimal sehingga strategi yang dilakukan berupa modifikasi dukungan peer group (13). Peran peer group diharapkan dapat memberikan pengaruh positif terkait perilaku diet dan pengetahuan gizi dalam pencapaian tubuh ideal (14). Tujuan penelitian ini dilakukan untuk menganalisis efektifitas peer group aktivitas terhadap kepatuhan aktivitas fisik, kepatuhan diet, penurunan berat badan dan persen lemak tubuh remaja overweight.

\section{METODE}

Penelitian ini merupakan penelitian eksperimental dengan kontrol random (Randomized Controlled Trial) menggunakan rancangan eksperimental ulang pretest posttest control group design. Populasi dalam penelitian ini adalah semua remaja akhir di salah satu Perguruan Tinggi Negeri di Kota Semarang. Subjek penelitian adalah bagian dari populasi dengan kriteria inklusi sebagai berikut: berjenis kelamin perempuan, IMT $\geq 23 \mathrm{~kg} / \mathrm{m}^{2}$, usia remaja akhir 18-21 tahun dan bersedia menjadi subjek penelitian. Klasifikasi umur remaja menurut Depkes 2009 yaitu masa remaja awal pada umur 12 s.d 16 tahun dan masa remaja akhir pada umur 17 s.d 25 tahun (15). Alasan pemilihan rentang usia tersebut adalah masa dengan kemungkinan sangat besar dalam mengalami ketidakpuasan akan bentuk tubuh karena dalam masa pengungkapan identitas diri sehingga sedang fokus memperhatikan penampilan diri dan selektif dalam mencari teman sebaya (14). Jumlah subjek penelitian ini sebanyak 26 orang yang terdiri dari kelompok perlakuan sebanyak 13 orang dan kelompok kontrol 13 orang. Penentuan jumlah subjek penelitian dihitung menggunakan rumus Lemeshow dengan tingkat kepercayaan Z $\alpha$ sebesar 1,96 dan kekuatan uji Z $\beta$ sebesar 0,842 . Rata-rata penurunan berat badan pada kelompok perlakuan sebesar 71,42 dan kelompok kontrol sebesar 52,1 dengan simpang baku penurunan berat badan sebesar 17 gram (16).

Kelompok perlakuan diberi intervensi secara kelompok (peer group) berupa peningkatan aktivitas fisik berupa jogging minimal selama 30 menit setiap hari pukul 05.00, kemudian naik turun tangga sebanyak 24 anak tangga disela-sela aktivitas perkuliahan dengan frekuensi 10 kali. Pengurangan asupan energi sebesar minimal 300kkal/hari dari kebutuhan individu dengan cara mengganti kudapan pagi, siang, dan malam dengan masing-masing satu porsi buah tanpa diolah selama empat minggu. Kelompok kontrol diberi perlakuan yang sama hanya saja dilakukan secara mandiri.

Data identitas subjek dikumpulkan dengan wawancara menggunakan formulir. Data berat badan dan tinggi badan digunakan sebagai dasar menghitung IMT. Kategori status gizi berdasarkan IMT menurut Asia Pasifik yaitu underweight $\left(<18,5 \mathrm{~kg} / \mathrm{m}^{2}\right)$; normal $\left(18,50-22,99 \mathrm{~kg} / \mathrm{m}^{2}\right)$; overweight $\left(23,00-24,99 \mathrm{~kg} / \mathrm{m}^{2}\right)$; obesitas I $(25,00$ $\left.29,99 \mathrm{~kg} / \mathrm{m}^{2}\right)$ dan obesitas II $\left(>30 \mathrm{~kg} / \mathrm{m}^{2}\right)$. Data persen lemak tubuh diukur menggunakan Body Composition Analyzer kemudian diklasifikasikan menjadi normal bila persen lemak tubuh $\leq 26,7 \%$ dan tinggi bila $>26,7 \%$ (17). Data aktivitas fisik dikumpulkan menggunakan formulir kemudian diklasifikasikan dengan kategori cukup bila $\geq 3$ kali dalam seminggu melaksanakan aktivitas fisik dan kurang jika $<3$ kali. Data kepatuhan diet diambil berdasarkan hasil recall $2 \times 24$ jam secara acak setiap minggunya selama 4 minggu. Asupan energi dikategorikan menjadi cukup bila tingkat konsumsi (perbandingan antara asupan dengan kebutuhan) $\leq 100 \%$ dan lebih bila $>100 \%$. Pengukuran kepatuhan aktivitas fisik, kepatuhan diet, perubahan berat badan dan persen lemak tubuh dilakukan ulang setiap minggu sekali selama empat minggu.

Perbedaan kepatuhan aktivitas fisik dan kepatuhan diet antara kelompok perlakuan dan kelompok kontrol dianalisis menggunakan Chi Square Test (18). Perbedaan penurunan berat badan dan persen lemak tubuh antara kelompok perlakuan dan kelompok kontrol dianalisis menggunakan ANOVA Repeated Measure Test.

\section{HASIL}

Karakteristik subjek penelitian sebelum perlakuan disajikan pada Tabel 1. Sebagian besar subjek penelitian 
memiliki kebiasaan olahraga kurang dari 3 kali dalam seminggu sebanyak 22 orang $(84,6 \%)$ dan selebihnya lebih dari tiga kali dalam seminggu sebanyak 4 orang $(15,4 \%)$. Sebagian besar subjek asupan energi lebih dari $100 \%$ dari kebutuhan sebanyak 23 orang $(88,5 \%)$ dan selebihnya kurang dari $100 \%$ dari kebutuhan yaitu 3 orang $(11,5 \%)$. Status gizi menurut indek masa tubuh (IMT) sebagian besar subjek termasuk kategori obesitas sebanyak 21 orang $(80,8 \%)$ dan selebihnya kategori overweight yaitu 5 orang $(19,2 \%)$. Hasil pengukuran persen lemak tubuh sebagian besar subjek termasuk kategori tinggi sebanyak 20 orang $(77,0 \%)$ dan selebihnya kategori normal yaitu 6 orang $(23,0 \%)$.

Tabel 1. Karakteristik subjek sebelum perlakuan

\begin{tabular}{|c|c|c|c|c|c|c|}
\hline \multirow[t]{2}{*}{ Variabel } & \multicolumn{2}{|c|}{$\begin{array}{c}\text { Perlakuan } \\
(n=13)\end{array}$} & \multicolumn{2}{|c|}{$\begin{array}{c}\text { Kontrol } \\
(n=13)\end{array}$} & \multicolumn{2}{|c|}{$\begin{array}{c}\text { Total } \\
(n=26)\end{array}$} \\
\hline & $n$ & $\%$ & $n$ & $\%$ & $n$ & $\%$ \\
\hline \multicolumn{7}{|l|}{ Aktivitas Fisik } \\
\hline Cukup & 1 & 7,7 & 3 & 23,0 & 4 & 15,4 \\
\hline Kurang (<3 kali) & 12 & 92,3 & 10 & 77,0 & 22 & 84,6 \\
\hline \multicolumn{7}{|l|}{ Asupan Energi } \\
\hline Cukup & 1 & 7,7 & 2 & 15,4 & 3 & 11,5 \\
\hline Lebih & 12 & 92,3 & 11 & 84,6 & 23 & 88,5 \\
\hline \multicolumn{7}{|l|}{ Indek Masa Tubuh } \\
\hline Overweight & 2 & 15,4 & 3 & 23,1 & 5 & 19,2 \\
\hline Obesitas & 11 & 84,6 & 10 & 76,9 & 21 & 80,8 \\
\hline \multicolumn{7}{|l|}{ Persen Lemak Tubuh } \\
\hline Normal & 2 & 15,4 & 4 & 30,7 & 6 & 23,0 \\
\hline Tinggi & 11 & 84,6 & 9 & 69,3 & 20 & 77,0 \\
\hline
\end{tabular}

Hasil analisis menggunakan Chi-Square Test menunjukkan ada perbedaan yang bermakna antara tingkat kepatuhan aktivitas fisik pada kelompok perlakuan dan kelompok kontrol pada aktivitas fisik minggu pertama, kedua, ketiga dan keempat $(p<0,00)$. Sebaliknya, tidak ada perbedaan yang bermakna antara tingkat kepatuhan diet pada kelompok perlakuan dan kelompok kontrol pada diet minggu pertama, kedua, ketiga dan keempat $(p=1,000$, $p=0,619, p=0,691$, dan $p=0,431$ ).

Tabel 2. Perbedaan kepatuhan aktivitas fisik dan kepatuhan diet antara kelompok perlakuan dan kontrol

\begin{tabular}{|c|c|c|c|c|c|}
\hline \multirow{3}{*}{ Variabel } & \multicolumn{4}{|c|}{ Kelompok } & \multirow{3}{*}{$\mathbf{P}$} \\
\hline & \multicolumn{2}{|c|}{ Perlakuan } & \multicolumn{2}{|c|}{ Kontrol } & \\
\hline & $\mathbf{n}$ & $\%$ & $\mathrm{n}$ & $\%$ & \\
\hline \multicolumn{6}{|l|}{ Aktivitas Fisik } \\
\hline \multicolumn{6}{|l|}{ Minggu 1} \\
\hline Patuh & 13 & 100 & 7 & 53,8 & 0,015 \\
\hline Tidak Patuh & 0 & 0 & 6 & 46,2 & \\
\hline \multicolumn{6}{|l|}{ Minggu 2} \\
\hline Patuh & 13 & 100 & 4 & 30,8 & 0,000 \\
\hline Tidak Patuh & 0 & 0 & 9 & 69,2 & \\
\hline \multicolumn{6}{|l|}{ Minggu 3} \\
\hline Patuh & 13 & 100 & 4 & 30,8 & 0,000 \\
\hline Tidak Patuh & 0 & 0 & 9 & 69,2 & \\
\hline \multicolumn{6}{|l|}{ Minggu 4} \\
\hline Patuh & 13 & 100 & 2 & 15,4 & $0,00 \quad 0$ \\
\hline Tidak Patuh & 0 & 0 & 11 & 84,6 & \\
\hline \multicolumn{6}{|l|}{ Kepatuhan Diet } \\
\hline \multicolumn{6}{|l|}{ Minggu 1} \\
\hline Patuh & 11 & 84,6 & 11 & 84,6 & 1,000 \\
\hline Tidak Patuh & 2 & 15,4 & 2 & 15,4 & \\
\hline
\end{tabular}

Tabel 2. Perbedaan kepatuhan aktivitas fisik dan kepatuhan diet antara kelompok perlakuan dan kontrol (Lanjutan)

\begin{tabular}{|c|c|c|c|c|c|}
\hline \multirow{3}{*}{ Variabel } & \multicolumn{4}{|c|}{ Kelompok } & \multirow{3}{*}{$\mathbf{P}$} \\
\hline & \multicolumn{2}{|c|}{ Perlakuan } & \multicolumn{2}{|c|}{ Kontrol } & \\
\hline & $\mathbf{n}$ & $\%$ & $\mathbf{n}$ & $\%$ & \\
\hline \multicolumn{6}{|l|}{ Minggu 2} \\
\hline Patuh & 10 & 76,9 & 11 & 84,6 & 0,619 \\
\hline Tidak Patuh & 3 & 23,1 & 2 & 15,4 & \\
\hline \multicolumn{6}{|l|}{ Minggu 3} \\
\hline Patuh & 7 & 53,8 & 8 & 61,5 & 0,691 \\
\hline Tidak Patuh & 6 & 46,2 & 5 & 38,5 & \\
\hline \multicolumn{6}{|l|}{ Minggu 4} \\
\hline Patuh & 8 & 61,5 & 6 & 46,2 & 0,431 \\
\hline Tidak Patuh & 5 & 38,5 & 7 & 53,8 & \\
\hline
\end{tabular}

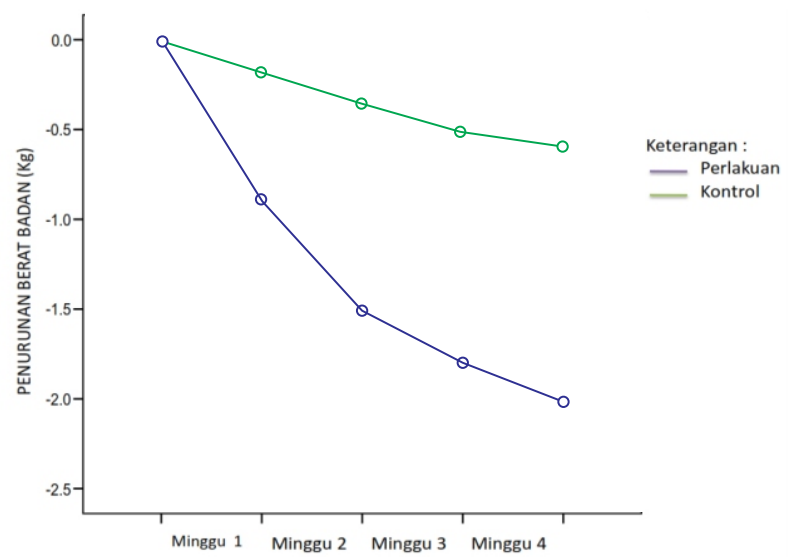

Gambar 1. Perbandingan penurunan berat badan subjek antara minggu 1, 2, 3, dan 4 antara kelompok perlakuan dan kontrol

Hasil analisis menggunakan uji ANOVA Repeated Measure Test menunjukkan ada perbedaan bermakna penurunan berat badan antara kelompok perlakuan dan kelompok kontrol $(p=0,004)$ sebagaimana tersaji pada Gambar 1. Sejak minggu kedua, remaja pada kelompok perlakuan menunjukkan penurunan berat badan yang lebih besar dibandingkan kontrol. Pada akhir pengamatan, remaja pada kelompok perlakuan telah mengalami penurunan sebanyak $2,5 \mathrm{~kg}$, sedangkan pada kelompok kontrol penurunan maksimal hanya $0,5 \mathrm{~kg}$.

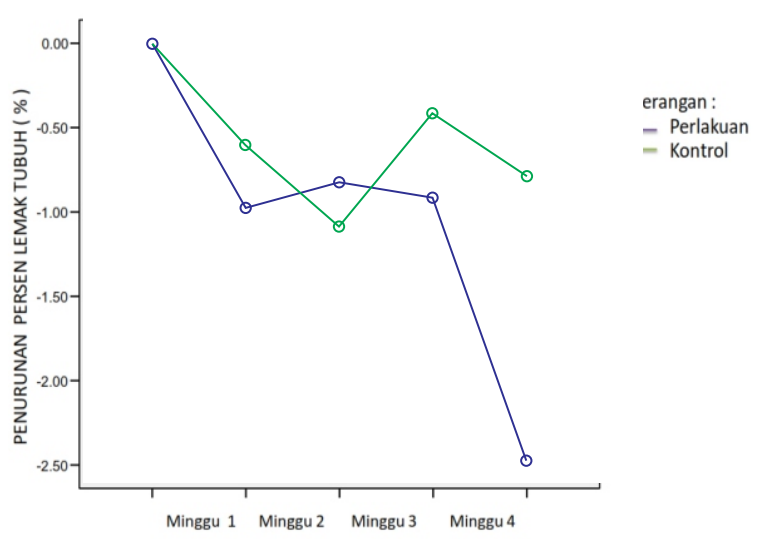

Gambar 2. Perbedaan penurunan persen lemak tubuh subjek antara minggu 1, 2, 3 dan 4 antara kelompok perlakuan dan kontrol 
Gambar 2 merupakan hasil analisis menggunakan uji ANOVA Repeated Measure Test yang menunjukan tidak ada perbedan bermakna antara penurunan persen lemak tubuh pada kelompok perlakuan dan kelompok kontrol ( $p=0,382)$. Gambar menunjukkan adanya fluktuasi, dalam minggu pertama kedua kelompok mengalami penurunan, namun terdapat kenaikan pada kelompok kontrol pada minggu ketiga. Hasil akhir menunjukkan penurunan persen lemak tubuh pada perlakuan jauh lebih besar.

\section{DISKUSI}

Salah satu upaya pengaturan berat badan remaja terkait dengan aktivitas fisik dan perilaku makan (10). Aktivitas fisik dihubungkan dengan kesehatan fisik dan mental pada remaja. Penurunan aktifitas fisik pada remaja putri dihubungkan dengan karakteristik remaja, interpersonal, asmara dan kurang olah raga (8). Hasil monitoring kepatuhan aktivitas fisik yang diukur setiap minggu menunjukkan kepatuhan (100\%) pada kelompok perlakuan dari minggu pertama sampai minggu terakhir, sedangkan pada kelompok kontrol adanya penurunan tingkat kepatuhan pada minggu pertama sebanyak 53,8 \% yang patuh dan minggu ke empat hanya sebanyak $15,4 \%$ yang patuh (Tabel 2). Setelah intervensi ada perbedaan yang bermakna antara tingkat kepatuhan aktivitas fisik pada kelompok perlakuan dan kelompok kontrol baik pada intervensi minggu pertama, kedua, ketiga dan keempat. Hasil penelitian tersebut menunjukkan bahwa aktivitas peer group berpengaruh terhadap kepatuhan subjek dalam menjalankan kegiatan olahraga yang dianjurkan yaitu berupa joging setiap hari dengan durasi minimal 30 menit. Pemberdayaan peer group dalam memberikan motivasi untuk melakukan aktivitas cukup efektif bagi remaja, dikarenakan peer group memberikan pengaruh adopsi yang lebih kuat terhadap perilaku kelompoknya dan merupakan kunci utama aktifitas fisik pada remaja (8). Caccavale et al., pun menyatakan peer group penting dalam pengembangan citra tubuh dan telah terbukti meningkatkan aktivitas fisik dan memotivasi untuk berolahraga (7). Edukasi teman sebaya (peer group) lebih memberikan rasa aman dan nyaman pada remaja dibandingkan edukasi yang diberikan oleh orang dewasa. Penelitian membuktikan anak lebih aman menceritakan masalahnya ke teman sebayanya dibandingkan ke orang dewasa, dikarenakan orang dewasa sering tidak menghargai kerahasiaan masalah yang diceritakan anak (19). Hal ini berarti aktivitas peer group cukup efektif untuk menjaga kepatuhan aktivitas fisik (11).

Hasil penelitian Septiana et al., menunjukkan bahwa remaja akhir hanya mengonsumsi serat rata-rata 3,91 gram diimbangi dengan asupan tinggi energi dan rendah zat gizi mikro menjadi faktor risiko terjadinya obesitas sentral (4). Oleh karena itu pada penelitian ini, anjuran untuk mengurangi asupan energi sebanyak minimal 300kkal dengan mengganti snack pagi, sore dan malam berupa junk food dengan sayur atau buah dianjurkan dalam peer group ini. Peningkatan konsumsi sayur dan buah sebagai sumber serat berkaitan dengan penurunan berat badan pada remaja putri $(20,21)$. Hasil uji statistik menunjukkan tidak ada perbedaan yang bermakna antara tingkat kepatuhan diet pada kelompok perlakuan dan kelompok kontrol. Hal ini kemungkinan karena kelemahan metode recall yang digunakan dalam pengukuran kepatuhan diet yaitu kecenderungan melaporkan underestimate (asupan yang lebih sedikit) pada subjek yang gemuk. Hingga minggu keempat tingkat kepatuhan subjek pada kelompok kontrol menurun lebih banyak $(46,2 \%)$, dibanding kelompok perlakuan $(61,5 \%)$. Hal ini menunjukkan bahwa peran teman dalam mempertahankan kepatuhan terhadap diet cukup besar dibanding pada kelompok kontrol yang terjadi penurunan kepatuhan lebih banyak. Pengaruh lingkungan, seperti teman sebaya berdampak pada remaja dalam perilaku diet atau perilaku pengendalian berat badan $(10,12,19)$. Upaya mempertahankan kepatuhan jangka panjang untuk mengikutsertakan kebiasaan diet yang baru ke dalam gaya hidupnya, maka dukungan kelompok atau teman sebaya sangat dianjurkan. Ketidakpatuhan dalam menjalankan diet dapat dipengaruhi oleh beberapa faktor salah satunya adalah faktor kesibukan, faktor lingkungan, keluarga dan paparan sosial media (2) dapat mempengaruhi seseorang dalam bertindak termasuk dalam melakukan diet. Oktaviani et al., pun menyatakan bahwa teman memiliki pengaruh yang sangat kuat terhadap pemilihan makanan. Perilaku remaja mulai banyak dipengaruhi oleh teman, termasuk perilaku makan. Remaja cenderung memilih makanan yang dapat diterima di kalangan peer group (22).

Hasil monitoring terhadap berat badan subjek penelitian yang dilakukan setiap minggu menunjukkan penurunan berat badan antara minggu pertama, kedua, ketiga dan keempat pada kelompok perlakuan dan kontrol. Rerata penurunan berat badan awal dan akhir minggu ke empat pada kelompok perlakuan sebesar 2,00kg sedangkan pada kelompok kontrol sebesar 0,59kg, sehingga penurunannya lebih besar pada kelompok perlakuan. Hasil analisis menggunakan uji ANOVA Repeated Measure menunjukan ada perbedan yang bermakna antara penurunan berat badan pada kelompok perlakuan dan kelompok kontrol. Gambar 1 memberikan kesimpulan bahwa aktivitas peer group cukup efektif bagi kelompok remaja untuk menurunkan berat badan, hanya saja semakin lama penurunan semakin melambat. Cherrington et al., menyatakan bahwa dukungan aktivitas peer group dapat menjadi salah satu strategi penurunan berat badan dan mempertahankan berat badan ideal terutama pada wanita (23). Keberadaan kelompok peer group sangat membantu dalam memotivasi seseorang untuk melakukan upaya penurunan berat badan dengan perasaan senasib untuk memenuhi kebutuhan dan tujuan bersama dalam mempengaruhi kebiasaan makan pada remaja putri dan mengatasi rasa tidak percaya diri atau depresi pada remaja obesitas (24). Peer group juga memberikan dukungan yang kuat pada remaja, baik secara individu ataupun secara kelompok yang sangat diperlukan untuk melakukan perubahan perilaku (25). Hal ini berarti bahwa aktivitas peer goup cukup efektif untuk menurunkan berat badan subjek.

Persen lemak tubuh mengalami penurunan pada kelompok perlakuan, namun secara statistik menggunakan uji ANOVA Repeated Measure menunjukan tidak ada perbedan yang bermakna antara penurunan persen lemak tubuh pada kelompok perlakuan dan kelompok kontrol $(p=0,382)$. Penurunan persen lemak tubuh secara bermakna terjadi setelah minggu keempat perlakuan, hal ini terjadi karena pada tingkat aktivitas sedang dan pengurangan asupan energi yang ringan yaitu $300 \mathrm{kkal}$ per hari tidak mengakibatkan tubuh harus membongkar lemak dalam waktu yang cepat, kekurangan energi pada minggu pertama sampai ketiga belum membuat tubuh membongkar lemak dalam jumlah besar untuk digunakan sebagai sumber energi. Penurunan persen lemak tubuh pada minggu pertama dan ketiga hanya sedikit 
dibandingkan dengan pada minggu keempat. Hal tersebut menunjukkan bahwa kehilangan berat badan sangat besar pada awal pengamatan jika mengurangi asupan makan, kemudian penurunan berat badan semakin lama semakin lambat (26). Penelitian ini sejalan dengan Narayani et al., penurunan lemak tubuh dan kolesetrol secara bermakna setelah pada mingu keenam (27).

Penurunan lemak tubuh disebabkan oleh meningkatnya aktifitas fisik pada subjek yang yang semula melakukan olahraga hanya seminggu sekali menjadi 3 kali atau lebih dalam seminggu dengan intensitas rendah yang mana sumber energi yang dibutuhkan berasal dari pembakaran cadangan lemak dalam tubuh. Tubuh akan menggunakan cadangan glikogen, protein dan lemak tubuh untuk memenuhi kebutuhan energi pada saat tubuh melakukan

\section{DAFTAR PUSTAKA}

1. Kementerian Kesehatan RI. Riset Kesehatan Dasar. Jakarta: Badan Penelitian dan Pengembangan Kesehatan; 2013: hal. 223-225.

2. Field AE, Javaras KM, Aneja P, et al. Family, Peer and Media Predictors of Becoming Eating Disordered. Archives of Pediatrics and Adolescent Medicine. 2008; 162(6): 574-579.

3. Mackey ER and La Greca AM. Adolescents' Eating, Exercise, and Weight Control Behaviors: Does Peer Crowd Affiliation Play a Role? Journal of Pediatric Psychology. 2007; 32(1): 13-23

4. Septiana P, Nugroho FA, dan Wilujeng CS. Konsumsi Junk Food dan Serat pada Remaja Putri Overweight dan Obesitas yang Indekos. Jurnal Kedokteran Brawijaya. 2018; 30(1): 61-67.

5. Keast DR, Nicklas TA, and O'Neil CE. Snacking is Associated with Reduced Risk of overweight and Reduce Abdominal Obesity in Adolescents: National Health and Nutrition Examination Survey (NHANES) 1999-2004. The American Journal of Clinical Nutrition. 2010; 92(2): 428-435.

6. Gooding HC, Milliren C, Austin SB, Sheridan MA, and McLaughlin KA. Exposure to Violence in Childhood Is Associated with Higher Body Mass Index in Adolescence. Child Abuse and Neglect. 2015; 50: 151-158.

7. Caccavale LJ, Farhat T, and Iannotti RJ. Social Engagement in Adolescence Moderates the Association between Weight Status and Body Image. Body Image. 2012; 9(2): 221-226.

8. Davison KK and Jago R. Change in Parent and Peer Support Across Ages 9 to $15 \mathrm{yr}$ and Adolescent Girls Physical Activity. Medicine and Science in Sports and Exercise. 2009; 41(9): 1816-1825.

9. Jelalian E, Sato A, and Hart CN. The Effect of GroupBased Weight Control Intervention on Adolescent Psychosocial Outcomes: Perceived Peer Rejection, Social Anxiety and Self-Concept. Children's Health Care. 2011; 40(3): 197-211.

10. Tshililo RA, Netshikweta LM, Tshitangano GT, and Nemathaga HL. Factors Influencing Weight Control Practices Amongst the Adolescent Girls in Vhembe District of Limpopo Province, South Africa. African aktivitas fisik. Aktivitas fisik yang dilakukan pada intensitas rendah sampai sedang dalam waktu 30 menit atau lebih akan membakar lemak. Hal ini berarti bahwa aktivitas peer group efektif menurunkan persen lemak tubuh setelah minggu keempat.

Hasil penelitian ini menyimpulkan aktivitas peer group efektif dalam meningkatkan kepatuhan aktivitas fisik dan menurunkan berat badan pada remaja overweight sebagaimana pendapat Salvy et al., (28) namun kurang efektif untuk menjaga kepatuhan diet dan menurunkan persen lemak tubuh pada remaja overweight. Aktivitas peer group dapat digunakan sebagai salah satu cara atau melengkapi metode yang sudah ada dalam upaya mengatasi overweight atau obesitas pada remaja.

Journal of Primary Health Care \& Family Medicine. 2016; 8(2): 1-4.

11. Rancourt D, Leahey TM, LaRose JG, and Crowther JH. Effects of Weight-Focused Social Comparisons on Diet and Activity Outcomes among Overweight and Obese Young Women. Obesity. 2015; 23(1): 8589.

12. Woolford SJ, Sallinen BJ, Schaffer S, and Clark SJ. Eat, Play, Love Adolescent and Parent Perceptions of the Components of a Multidisciplinary Weight Management Program. Clinical Pediatrics. 2012; 51(7): 678-684.

13. Ali MM, Amialchuk A, and Heiland FW. WeightRelated Behavior among Adolescents: The Role of Peer Effects. PLoS ONE. 2011; 6(6): 1-9.

14. Kurniawan MY, Briawan D, dan Caraka RE. Persepsi Tubuh dan Gangguan Makan pada Remaja. Jurnal Gizi Klinik Indonesia. 2015; 11(3): 105-114.

15. Departemen Kesehatan RI. Sistem Kesehatan Nasional. Jakarta: Depkes Rl; 2019.

16. Alrasyid H. Pengaruh Modifikasi Diet Rendah Kalori terhadap Berat Badan dan Lingkat Pinggang Wanita Obesitas Dewasa. Majalah Kedokteran Nusantara. 2007; 40(4): 267-273.

17. Gibson RS. Principlels of Nutritional Assessment. New York: Oxford University Press; 2005; pp. 273

18. Dahlan MS. Statistik untuk Kedokteran dan Kesehatan. Jakarta: Epidemiologi Indonesia; 2014: hal. 16.

19. Hidayati RN dan Ibnu F. Efektifitas Peer Group Education tentang Gizi Seimbang Terhadap Perilaku Gizi pada Anak Usia Sekolah. Jurnal Keperawatan Bina Sehat. 2014; 10(2): 1-6.

20. de Oliveira MC, Sichieri R, and Venturim MR. A LowEnergy-Dense Diet Adding Fruit Reduces Weight and Energy Intake in Women. Appetite. 2008; 51(2): 291295.

21. Hart CN, Jelalian E, Raynor HA, et al. Early Patterns of Food Intake in an Adolescent Weight Loss Trial as Predictors of BMI Change. Eating Behaviour. 2010; 11(4): 217-222.

22. Oktaviani WD, Saraswati LD, dan Rahfiludin MZ. Hubungan Kebiasaan Konsumsi Fast Food, Aktivitas 
Fisik, Pola Konsumsi, Karakteristik Remaja dan Orang Tua dengan Indeks Massa Tubuh (IMT) (Studi Kasus pada Siswa SMA Negeri 9 Semarang Tahun 2012). Jurnal Kesehatan Masyarakat. 2012; 1(2): 542-553.

23. Cherrington $A L$, Willig $A L$, Agne $A A$, Fowler $M C$, Dutton GR, and Scarinci IC. Development of $a$ Theory-Based, Peer Support Intervention to Promote Weight Loss among Latina Immigrants. BMC Obesity. 2015; 2(17): 2-9.

24. Bayyari WD, Henry LJ, and Jones C. Dieting Behaviours, Obesity and Predictors of Dieting among Female College Students at Palestina Universities. Eastern Mediterranean Health Journal.
2013; 19(1): 30-36

25. Sriutari D. Pengaruh Peer Group terhadap Kebiasaan Makan Remaja Putri. [Tugas Akhir]. Universitas Indonesia, Depok. 2008.

26. Wong DL. Buku Ajar Keperawatan Pediatrik. Jakarta: ECG; 2009 .

27. Narayani $U$ and Raj RLSP. Effect of Aerobic Training on Percentage of Body Fat, Total Cholesterol and HDL-C among Obese Women. World Journal of Sports Scinces. 2010; 3(1): 33-36.

28. Salvy SJ, de la Haye K, Bowker JC, and Hermans RCJ. Influence of Peers and Friends on Children's and Adolescents' Eating and Activity Behaviors. Physiology and Behavior. 2012; 106(3): 396-378. 